\title{
Modelo experimental de cultura primária de melanoma metastático por punção aspirativa de agulha fina ${ }^{1}$
}

\author{
Experimental model of primary cultured metastatic melanoma \\ by fine needle aspiration
}

\author{
Andrea Fernandes de Oliveira ${ }^{2}$, Alfredo Gragnani ${ }^{3}$, Renato Santos Oliveira Filho ${ }^{3}$, Ivan Dunshee de Abranches Oliveira \\ Santos $^{4}$, Silvana Gaiba de França ${ }^{5}$, Mílvia Maria Simões e Silva Enokihara ${ }^{6}$, Lydia Masako Ferreira ${ }^{7}$ \\ 1. Trabalho realizado no Laboratório de Cultura de Células da Disciplina de Cirurgia Plástica da Universidade Federal de São Paulo - Escola \\ Paulista de Medicina (UNIFESP/EPM). São Paulo. \\ 2. Residente da Disciplina de Cirurgia Plástica da UNIFESP/EPM. \\ 3. Professor afiliado da Disciplina de Cirurgia Plástica da UNIFESP/EPM. \\ 4. Prof. Adjunto da Disciplina de Cirurgia Plástica da UNIFESP/EPM. \\ 5. Pós-graduando do Programa de Pós-graduação em Cirurgia Plástica da UNIFESP/EPM. \\ 6. Médico do Departamento de Patologia da UNIFESP/EPM. \\ 7. Prof. Titular e Coordenador do Programa de Pós-graduação em Cirurgia Plástica UNIFESP/EPM.
}

\section{RESUMO}

Objetivo: Estabelecer um modelo experimental de cultura primária de melanoma metastático por punção aspirativa por agulha fina (PAAF). Métodos: Duas culturas primárias de células de melanoma metastático através de PAAF foram desenvolvidas a partir de pacientes submetidos à excisão de lesões metastáticas e identificadas por imunohistoquímica utilizando os marcadores S-100 e MB-45, específicos para melanoma. Resultados: O diagnóstico da cultura foi confirmado através da imunohistoquímica. A técnica oferece vantagens como pequena morbidade e invasibilidade, além do mais, a mesma lesão pode ser puncionada seqüencialmente durante o tratamento do doente. Conclusão: O estabelecimento de cultura primária de melanoma metastático a partir de punção aspirativa por agulha fina mostrou-se uma técnica viável. Descritores: Melanoma, Excisão de Linfonodos. Cultura de Células. Biópsia por Agulha. Diagnóstico.

\section{ABSTRACT}

Purpose: Establish an experimental model of metastatic melanoma primary culture cells from fine-needle aspiration biopsies (FNAB). Methods: Two metastatic melanoma primary culture cells from (FNAB) have been developed from patients who had been submitted to excision of metastatic lesions and they were identified by immunohistochemical analyses using S100 and MB-45 melanoma markers. Results: The culture diagnostic was confirmed by immunohistochemical. The technique of FNAB offers the advantage of providing a sequential analysis of the same tumor nodules throughout treatment, and is a minimally invasive procedure with almost no associated morbidity. Conclusion: The establishment of metastatic melanoma primary culture from FNAB samples showed a viable technique.

Key words: Melanoma. Lymph Node Excision. Cell Culture. Biopsy, Needle. Diagnosis.

\section{Introdução}

A primeira tentativa de cultura de célula proveniente de melanoma foi realizada por Burrow em 1914. Porém, somente em 1966, Brown e colaboradores descreveram o primeiro crescimento de melanoma "in vitro" com sucesso. Em 1967, Ronsdahl e Hsu descreveram o desenvolvimento de oito linhagens celulares de melanoma humano. ${ }^{1}$

Com o surgimento da quimioterapia, linhagens celulares imortalizadas ou pré-estabelecidas de melanoma passaram a ser utilizadas para testar a eficácia das drogas quimioterápicas sobre esse tipo de célula tumoral. ${ }^{2}$ A linhagem celular imortalizada de tumores humanos é obtida a partir de uma cultura primária e mantém in vitro características fenotípicas das células in vivo e a capacidade de proliferação contínua; essas células imortalizadas são fornecidas pelos centros de pesquisa que as desenvolveram. ${ }^{2} \mathrm{O}$ fator limitante da utilização dessas células em experimentos se deve ao fato de que elas representam a biologia tumoral de uma linhagem específica de melanoma de um determinado paciente que pode não ser aplicado aos outros. ${ }^{3}$ Riker e col. ${ }^{4}$ mostraram que a punção aspirativa por agulha fina (PAAF) é um eficiente método na coleta de células, capaz de gerar seqüencialmente e da mesma lesão, seja ela primária ou metastática, células viáveis para o desenvolvimento de culturas primárias e conseqüentemente, linhagens celulares. ${ }^{4}$ A PAAF é um procedimento minimamente invasivo, com baixíssima morbidade relatada. A contaminação por bactérias, ou devido à necrose tumoral, ou ainda por fibroblastos é praticamente inexistente. Esse método também permite uma 
análise seqüencial do mesmo nódulo durante um tratamento não cirúrgico, enquanto a biópsia excisional oferece material para cultura em um único momento. Outro ponto importante é que imediatamente após a coleta é possível analisar a quantidade, a qualidade e a morfologia das células coletadas. $^{4,5} \mathrm{O}$ objetivo desse estudo foi obter cultura primária de melanoma através de punção aspirativa por agulha fina de linfonodos metastáticos

\section{Métodos}

As células de melanoma foram obtidas de linfonodos metastáticos de seis pacientes, isoladas e cultivadas a partir de método descrito por Riker e col. ${ }^{4}$, sendo esse protocolo seguido inicialmente. Todos os procedimentos foram realizados em ambiente de fluxo laminar. O meio RPMI 1640 foi utilizado após suplementação com soro fetal bovino (SFB) a $10 \%$, L-glutamina $0,03 \%$, penicilina $100 \mathrm{U} / \mathrm{ml}$, estreptomicina $10 \mathrm{ig} / \mathrm{ml}$, ciprofloxacina $10 \mathrm{ìg} / \mathrm{ml}$, anfotericina $\mathrm{B}$ 0,5 ìg/ml para um total de 1 litro; o pH foi ajustado em 7,4. O meio foi esterilizado em filtro de 0,22 ìm e armazenado a temperatura de $-4^{\circ} \mathrm{C}$. Para coleta das células, $10 \mathrm{ml}$ do meio foi transferido para um tubo cônico de $15 \mathrm{ml}$ e mantido à temperatura ambiente. A punção aspirativa por agulha fina foi realizada no intra-operatório de linfadenectomia de seis pacientes com melanoma metastático com intuito de colher células dos linfonodos acometidos para realização de cultura primária. Os pacientes foram informados sobre o método e objetivo do trabalho e assinaram termo de consentimento. Seringa de $10 \mathrm{ml}$ acoplada a uma agulha 25 x 0,7 mm foi utilizada para aspirar células dos linfonodos metastáticos; a agulha foi introduzida no nódulo e mantida no interior do mesmo enquanto aplicamos uma pressão negativa contínua através da seringa. Antes de retirar a agulha, a pressão deve ser desfeita e o espécime coletado foi colocado em tubo cônico de $15 \mathrm{ml}$ com $10 \mathrm{ml}$ de meio de cultura no seu interior. Esse material foi levado num intervalo máximo de trinta minutos para o laboratório, onde foi centrifugado durante cinco minutos com velocidade de $1300 \mathrm{rpm}$. As células foram ressuspensas com $10 \mathrm{ml}$ de meio de cultura e novamente centrifugadas na mesma velocidade e intervalo de tempo, para retirar o máximo de impurezas. As células foram ressuspensas em $5 \mathrm{ml}$ de meio de cultura e colocadas em uma garrafa de cultura de $25 \mathrm{~cm}^{2}$, que foi mantida numa estufa com temperatura de $37^{\circ} \mathrm{C}$ em $5 \%$ de $\mathrm{CO}^{2}$.

A troca do meio de cultura foi realizada a cada 2 dias. Após a primeira semana de cultivo, o meio RPMI 1640 sem ciprofloxacina foi utlizado. Quando as garrafas de $25 \mathrm{~cm}^{2}$ atingiram uma confluência de 80\% (Figura 1), o conteúdo de uma garrafa de cultura era tripsinizado e sub-cultivado em duas garrafas do mesmo tamanho, seguindo o protocolo: inicialmente, o meio de cultura era aspirado e o conteúdo da garrafa lavado com versene, em seguida $2 \mathrm{ml}$ de tripsina era colocado na garrafa e observava-se no microscópio a soltura das células por um tempo máximo de 10 minutos, quando necessário submetia-se a garrafa a choques mecânicos. A tripsina era neutralizada com $4 \mathrm{ml}$ de meio de cultura, o conteúdo era aspirado e colocado num tubo cônico de 15 $\mathrm{ml}$ e levado para centrífuga por 5 minutos, o sobrenadante era aspirado e o botão de células era ressuspenso com $5 \mathrm{ml}$ de meio de cultura e dividido em 2 garrafas.

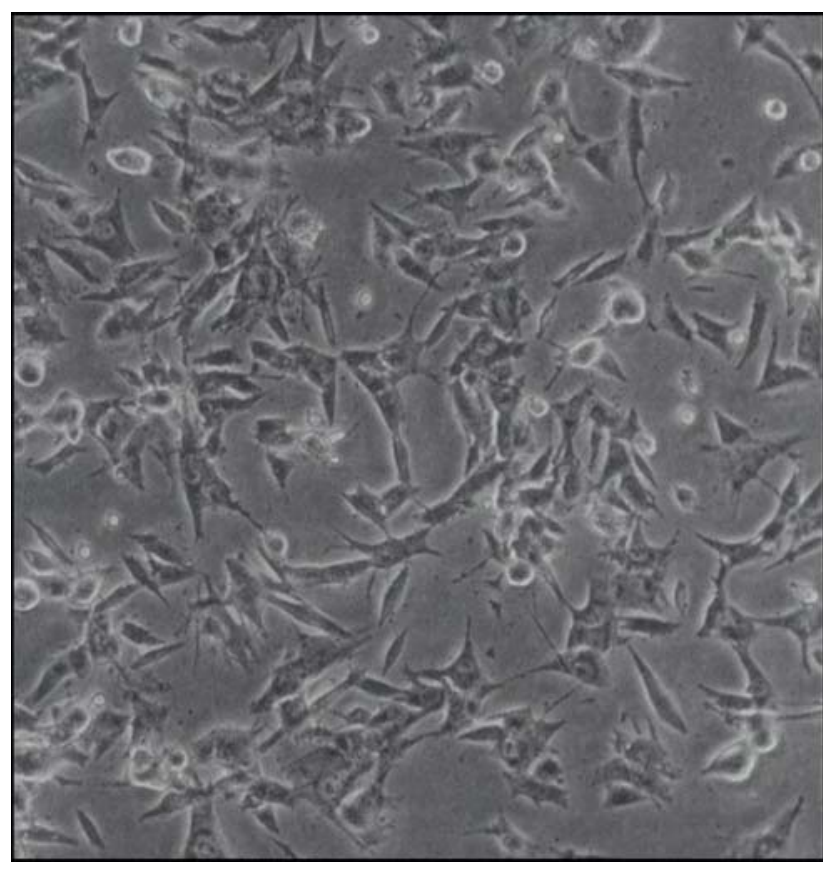

FIGURA 1 - Células de melanoma aderidas na garrafa de cultura apresentando 80\% de confluência.

Nesse mesmo procedimento, uma alíquota das células foi fixada em lâminas com microvials. O procedimento foi realizado utilizando micropipetas e foram colocados 40 ìl de polilisina em cada área da lâmina, que permaneceu em repouso durante 1 hora. Após esse intervalo, o excesso da polilisina foi aspirado e logo em seguida colocado 20 ìl da suspensão de células. Finalmente, após intervalo de 1 hora, o material foi fixado com 20 ìl de álcool absoluto. As lâminas foram armazenadas em frasco também com álcool absoluto e encaminhadas para o setor de Patologia. O diagnóstico da cultura foi confirmado através da imuno-histoquímica utilizando a proteína S-100 e HMB-45 (Human Melanoma Black), marcadores freqüentemente utilizados para diagnóstico do melanoma. O HMB-45 é utilizado devido sua especificidade na detecção de células de melanoma, mas em relação à proteína S-100 é menos sensível.O procedimento técnico consistiu de hidratação com álcool, lavagem em água corrente, bloqueio da peroxidase endógena, incubação do anticorpo primário e da peroxidase e a revelação da reação. Finalmente, as lâminas eram fixadas em álcool absoluto e as reações para HMB-45 e Proteína S100 foram lidas e anotadas. ${ }^{6}$

\section{Resultados}

O presente estudo desenvolveu duas culturas primárias de células de melanoma a partir de punção aspirativa por agulha fina. A primeira cultura foi cultivada até a segunda passagem e essa amostra foi congelada; a segunda amostra de células foi cultivada ate a oitava passagem, e também foi congelada. As células do primeiro paciente atingiram confluência de $80 \%$ da garrafa de cultura em 20 dias. No segundo paciente, foram necessários 30 dias para atingir a mesma confluência, porém após a quarta passagem ocorreu um aumento na velocidade de crescimento, e as células 
ocupavam toda a superfície da garrafa de cultura num espaço de oito dias. Durante o seu crescimento, as células apresentavam um tropismo para se agruparem (Figura 2).

Nas duas amostras relatadas as células apresentavam morfologia semelhante, entretanto, foram observados três formatos celulares distintos. Existiam células triangulares com dendritos, fusiformes e redondas (Figura 3).

O diagnóstico da cultura foi confirmado através da imunohistoquímica utilizando os marcadores S-100 e MB45, específicos para melanoma (Figura 4).

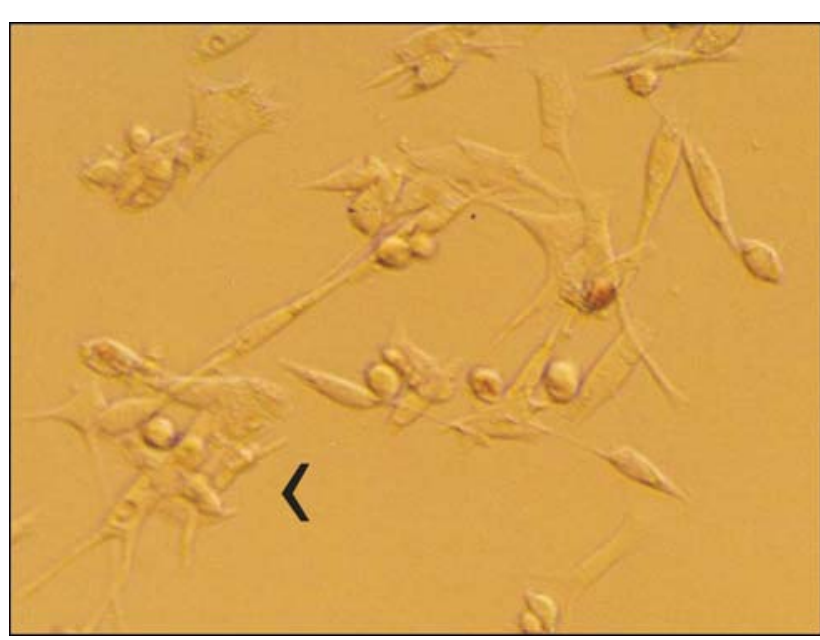

FIGURA 2 - Agrupamentos de células de melanoma metastático na garrafa de cultura.

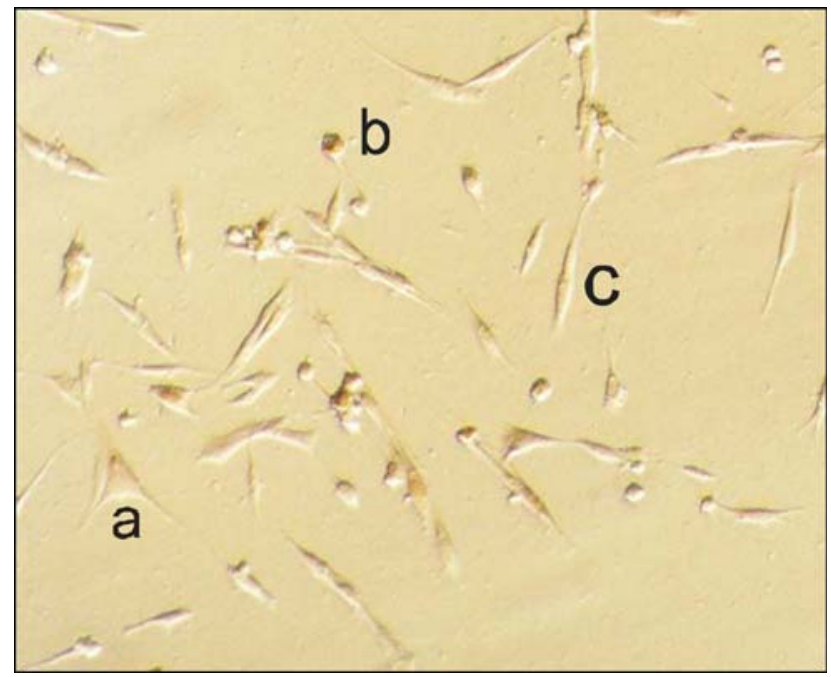

FIGURA 3 - Aspecto microscópico das células: triangulares(a), redondas(b) e fusiformes(c).

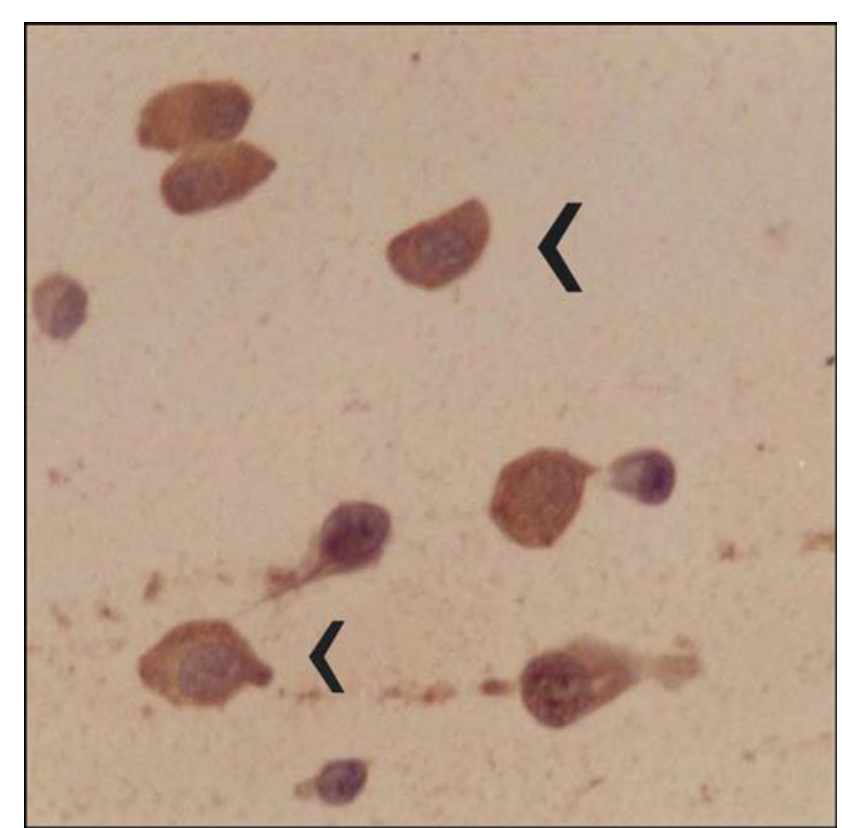

FIGURA 4 - Imunohistoquímica com MB-45 confirmando presença de células de melanoma (células com amplo citoplasma com grânulos de pigmentos acastanhados, presença de nucléolos proeminentes, por vezes binucleadas).

\section{Discussão}

Os linfonodos são um sítio comum de metástase do melanoma. A presença de linfonodos clinicamente positivos altera o prognóstico e o planejamento terapêutico do paciente (estadiamento III). A punção aspirativa por agulha fina é um procedimento minimamente invasivo, rápido, preciso e com morbidade mínima na avaliação de linfonodos suspeitos. ${ }^{4,7,8}$ A punção aspirativa por agulha fina do melanoma possui numerosas vantagens na análise de tumores primários e metastáticos. O material coletado pode ser avaliado imediatamente, fornecendo a qualidade, a quantidade e a morfologia celular., ${ }^{48}$ Behm e colaboradores mostraram que mútiplas aspirações de linfonodos benignos pode ser realizada sem formação de cicatriz ou alterações permanentes na circulação linfática da região com mínima alteração da arquitetura do linfonodo que afetaria a interpretação histológica. ${ }^{9}$ No presente estudo, os linfonodos apresentavam aspecto clínico e macroscópico de metástase de melanoma, estando indicado a sua retirada. Portanto a punção aspirativa foi realizada após sua retirada, com o nódulo sobre compressa na mesa cirúrgica. Não foi realizada punção de linfonodo suspeito ou benigno em paciente com melanoma. Não foi realizado análise estatística, pois o presente estudo é descritivo do modelo experimental de cultura primária de melanoma metastático por punção aspirativa. A maioria das culturas de células tumorais foi estabelecida a partir de biópsia excisional. ${ }^{2,3,10}$ Isto limita o estudo a um espaço de tempo isolado de uma única localização anatômica. ${ }^{4} \mathrm{O}$ uso de amostras tumorais sólidas implica na utilização de enzimas para separar as células tumorais, o que pode gerar contaminação da cultura por 
outras células, sendo mais comumente descrito a invasão por fibroblastos. ${ }^{11} \mathrm{~A}$ constatação do método PAAF como rápido, de baixo custo e com alta sensibilidade para diagnóstico de metástases, tornou possível realizar uma análise seqüencial de uma lesão ou de múltiplas lesões no mesmo paciente durante seu tratamento, gerando um meio para avaliar o microambiente tumoral e as suas interações com o sistema imune. ${ }^{4} \mathrm{O}$ desenvolvimento de cultura de células de melanoma através da PAAF apresentou dificuldades quanto ao tempo de confluência, o não crescimento de células e contaminação de amostras, sendo todos esses casos desprezados. O aprendizado produzido por esses casos foi fundamental para o sucesso nos casos apresentados. A cultura de células de melanoma metastático é fundamental para o seguimento clínico do paciente, pois possibilita o desenvolvimento futuro de estudos in vitro para a linhagem celular tumoral específica do paciente frente a vários agentes que possam interferir ou até mesmo parar o crescimento celular em cultura e que isso possa ser utilizado clinicamente como uma esperança ao paciente com melanoma com metástases. A utilização de drogas quimioterápicas, fatores de crescimento, agentes que desencadeiam apoptose, entre outras perpectivas, mostra a potencialidade desse modelo experimental.

\section{Conclusão}

A obtenção de cultura primária de melanoma metastático a partir de punção aspirativa por agulha fina é uma técnica viável.

\section{Referências}

1. Gerner RE, Kitamura H, Moore GE. Studies of tumor cells lines derived from patients with malignant melanoma. Oncology. 1975; 31:31-43.

2. Freshney RI. Culture of tumor tissue. In: Freshney RI. Culture of animal cells. 3ed. Wiley-Liss Inc; 1994. p 449-56.
3. Murray MR, Stout AP. The classification and diagnosis of human tumors by tissue culture methods. Text Rep Biol Med. 1954; 12:898-915.

4. Riker AI, Panelli MC, Kammula US, Wang E, Wunderlich J, Abati A, Fetsch P, Rosemberg SA e Marincola FM. Development and characterization of melanoma cells lines established by fine-needle aspiration biopsy: advances in the monitoring of patients with metastatic melanoma. Cancer Detect Prev. 1999; 23(5):387-96.

5. Basler GC, Fader DJ, Yahanda A, Sondak VK, Johnson TM. The utility of fine needle aspiration in the diagnosis of melanoma metastatic to lymph nodes. J Am Acad Dermatol. 1997; 36:403-8.

6. Enokihara MMSS. Estudo morfométrico e imunohistoquímico dos linfonodos sentinelas de pacientes com melanoma cutâneo primário [Tese-Doutorado]. Faculdade de Medicina da Universidade de São Paulo; 2003.

7. Perry MD, Hilliard FS, Johnston WW. Dignosis of metastatic malignant melanoma by fine needle aspiration byopsy: a clinical and pathologic correlation of 298 cases. J Natl Cancer Inst. 1986; 77: 1013-19.

8. Rodrigues LKE, Stanley PLL, Ljung B, Sagebiet RW, Burnside N, Hu TW, Ng BW, Miller III JR, Kashani-Sabet $M$. Fine needle aspiration in the diagnosis of metastatic melanoma. J Am Acad Dermatol. 2000; 42:735-40.

9. Behm Fg, O’Dowd GJ, Frable WJ. Fine-neddle aspiration effects on benign lymph node histology. Am J Clin Pathol. 1984; 82: 195-8.

10. Liao SK, Dent PB, McCulloch PB. Characterization of human malignant melanoma cell lines. I. Morphology and growth characteristics in culture. J Natl Cancer Inst. 1975; 54:1037-43.

11. Delcroix M, Libert A, Lejune F. Identification of fibroblastoid cell type in human melanoma cultures. J Natl Cancer Inst 1986; 77: 1171.

\section{Correspondência:}

Andrea Fernandes de Oliveira

Disciplina de Cirurgia Plástica

Rua Napoleão de Barros, $715 / 4^{\circ}$ andar

04024-002 São Paulo - SP

Tel: (011)5576-4118

drandreafernandes@terra.com.br
Conflito de interesse: nenhum Fonte de financiamento: nenhuma

Recebimento: 28/03/2005

Revisão: 25/04/2005

Aprovação: 23/05/2005

\section{Como citar este artigo:}

Oliveira AF, Gragnani A, Oliveira Filho RSO, Santos IDAO, França SG, Enokihara MMSS, Ferreira LM. Modelo experimental de cultura primária de melanoma metastático por punção aspirativa de agulha fina. Acta Cir Bras. [periódico na Internet] 2005 Set-Out;20(5). Disponível em URL: http://www.scielo.br/acb 